\title{
PEMIKIRAN IMAM TAQĪ AL-DĪN AL-SUBKĪ (683/1284-756/1355) BERKAITAN KRITERIA KENAMPAKAN ANAK BULAN ${ }^{1}$
}

\section{Imam Taqī al-Dīn al-Subkī (683/1284-756/1355) on Criteria for Lunar Crescent's Visibility Issues}

\author{
Mohd Saiful Anwar Mohd Nawawi \\ Khairussaadah Wahid ${ }^{3}$ \\ Saadan Man ${ }^{4}$ \\ Nazhatulshima Ahmad ${ }^{5}$ \\ Mohammaddin Abdul Niri ${ }^{6}$
}

\begin{abstract}
Taqī al-Dīn al-Subkī (d. 756/1355) has been unreservedly credited as one of the scholars in the fiqh and usul al-fiqh. His most important scholarly work Adillah fì Ithbät al-Ahillah, clearly
\end{abstract}

1 Penulisan ini dibiayai sebahagiannya oleh Geran Penyelidikan Universiti Malaya IIRG002D-19FNW "Penentuan Awal Bulan Hijrah: Analisis Perbandingan di Asia Tenggara" (Determination of Beginning of Hijrah Months: Comparison Analysis in Southeast Asia).

2 Senior Lecturer, Department of Fiqh and Usul, Academy of Islamic Studies, University of Malaya, 50603 Kuala Lumpur, saifulanwar@um.edu.my

3 Ph.D Candidate, Department of Fiqh and Usul, Academy of Islamic Studies, University of Malaya, 50603 Kuala Lumpur, khairussaadahwahid@gmail.com

4 Senior Lecturer, Department of Fiqh and Usul, Academy of Islamic Studies, University of Malaya, 50603 Kuala Lumpur, saadan@um.edu.my

5 Senior Lecturer, Department of Physics, Faculty of Science, University of Malaya, 50603 Kuala Lumpur, n_ahmad@um.edu.my

6 Senior Lecturer, Department of Fiqh and Usul, Academy of Islamic Studies, University of Malaya, 50603 Kuala Lumpur,mohammaddin@um.edu.my 
demonstrates his sholarship in the sciences of lunar crescent's visibility. It will then explore how his positions corresponds or are relevant to lunar crescent visibility criteria issues in the contemporary ages. This article concludes that al-Subki views on those isues are still relevant to the some current issues related to lunar crescent's visibility criteria.

Keywords: al-Subkī, crescents visibility, imkān al-rukyah

\section{PENDAHULUAN}

Terdapat 12 bulan dalam kalendar Hijrah yang telah diberikan nama-nama tertentu bermula dengan Muharam sehinggalah Zulhijjah. Kalendar Hijrah tidak terikat dengan sebarang musim menggunakan bulan sebagai rujukan untuk mengawal selia tempoh kitaran masa selama 354 atau 356 hari dalam setahun. Secara umumnya, kalendar ini digunakan oleh masyarakat Islam dalam menentukan 1 Ramadan, 1 Syawal dan 10 Zulhijah. Di samping itu juga, terdapat hari-hari kebesaran dalam agama Islam yang mempunyai kaitan secara langsung dengan kalendar Hijrah. Antara hari-hari kebesaran tersebut adalah 1 Muharam (Maal Hijrah), 10 Muharam (Asyura), 17 Rabiulawal (Maulidul Rasul), 27 Rejab (Isra' Mikraj), 15 Syaaban (Nisfu Syaaban), 27 Ramadan (Nuzul Quran) dan 9 Zulhijah (Hari Arafah). ${ }^{7}$ Selain itu, kalendar ini juga mempunyai hubungkait secara langsung dalam menentukan tarikh membayar zakat fitrah, tarikh puasa-puasa sunat, tempoh iddah, tempoh berpuasa, tempoh umur binatang peliharaan yang dikenakan zakat, i'tikaf, tempoh kifarat, penentuan nasab, tempoh mengandung dan sebagainya. ${ }^{8}$

Kalendar Hijrah mempunyai kaitan yang rapat dengan anak bulan. Ini kerana penentuan bagi awal bulan Hijrah adalah melibatkan anak bulan. Minat secara saintifik untuk mengetahui kebolehnampakan pertama anak bulan bermula sejak zaman Babylon kemudian diteruskan pada tamadun Yunani, Rom, Yahudi, Mesir, Aztec, Inca, Cina dan Hindu. ${ }^{9}$ Bagi ahli astronomi, adalah menjadi satu cabaran untuk melihat bulan yang paling kecil kerana ia melibatkan pelbagai faktor yang perlu diambil kira seperti astronomi,

7 Mohammad Ilyas, Sistem Kalendar Islam dari Perspektif Astronomi (Kuala Lumpur: Dewan Bahasa dan Pustaka, 1999), 77.

8 Abū al-Hasan Taqī al-Dīn 'Alī 'Abd al-Kāfī al-Subkī, Fatawā al-Subkī, vol. 1 (Qāhirah: Dār al-Ma‘ārif, t.t.), 227.

9 Mohammad Ilyas, Kalendar Islam Antarabangsa (Kuala Lumpur: Dewan Bahasa dan Pustaka, 1999), 30. 
meteorologi dan psikologi. ${ }^{10}$ Menurut Ilyas, dalam menentukan kenampakan anak bulan, ia tidak memadai dengan hanya bersandarkan kepada ilmu matematik semata-mata. Terdapat perbezaan yang ketara antara bulan dan matahari di mana matahari menghasilkan cahaya, manakala bulan tidak boleh menghasilkan cahaya. Cahaya yang dilihat daripada bulan merupakan cahaya yang dipancarkan daripada matahari. Oleh yang demikian, pencerap boleh melihat cahaya matahari walaupun matahari masih berada di bawah ufuk ketika matahari terbit. Ini disebabkan oleh adanya faktor biasan atmosfera. ${ }^{11}$ Ia berbeza dengan bulan atau anak bulan yang tidak mempunyai cahayanya sendiri. Walaupun anak bulan telah berada di atas ufuk, kecerahan langit yang dipancarkan oleh matahari mempengaruhi sama ada anak bulan boleh kelihatan ataupun tidak. Walaupun langit semakin gelap, terdapat faktor lain pula yang perlu diambil kira seperti pemupusan atmosfera. ${ }^{12}$ Oleh yang demikian, ia telah menyukarkan seseorang pencerap untuk melihat anak bulan, maka ahli astronomi telah merumuskan satu kriteria kenampakan anak bulan. Kriteria ini dirumuskan berdasarkan kepada rekod kenampakan atau menggunakan kaedah teoretikal dalam menjangkakan kemungkinan anak bulan boleh kelihatan. ${ }^{13}$

Justeru, artikel ini akan menjelaskan perbahasan kriteria kenampakan anak bulan berdasarkan pendapat al-Subkī dalam kitab Adillah fi Ithbāt al-Ahillah. Dalam membahaskan mengenai kriteria imkān al-rukyah, al-Subkī telah membahagikan bab khusus dalam menghuraikan hadis-hadis yang berkaitan dengan rukyah dan hisab. Seperti yang dinyatakan dalam matan hadis pertama; Rasulullah SAW bersabda: "Berpuasalah kamu apabila telah melihat anak bulan dan berbukalah apabila telah melihatnya. Jika pandangan kamu dilindungi oleh awan, maka hitunglah tiga puluh hari". Kedua; "Janganlah kalian berpuasa sehingga kalian melihat bulan dan jangan pula kalian berbuka sehingga kalian melihatnya. Apabila anak bulan terhalang oleh awan, maka kira-kirakanlah bilangannya (buatlah perhitungan hari baginya)." Ketiga; "Sesungguhnya umat yang buta huruf, tidak tahu menulis dan tidak tahu mengira, bulan adalah sekian sekian. Iaitu sesekali 29 hari dan sesekali lagi 30 hari". Perbahasan tiga hadis-hadis tersebut telah ditekankan oleh al-Subkī dari

10 Kordi, Ayman S., 'The Psychological Effect on Sightings of The New Moon', The Observatory, vol. 123 (2003): 219-222; Schaefer, Bradley E., 'Visibility of the Lunar Crescent', Quarterly Journal of the Royal Astronomical Society, vol. 29 (1988), 511.

11 Mohamad Ilyas, Kalendar Islam Antarabangsa, 11.

12 Yallop, Bernard D., A Method for Predicting the First Sighting of the New Crescent Moon (Cambridge: Nautical Almanac Office, 1997, disemak $1998=$ NAO Technical Notes, nr. 69

13 Mohamad Ilyas, Kalendar Islam Antarabangsa, 12. 
aspek tatabahasa Arab. Hadis pertama dan kedua menjelaskan tuntutan rukyah yang perlu menggunakan konsep imkān al-rukyah dan bukannya wujūd alhilāl mengikut pemahaman al-Subkī. Seterusnya, hadis ketiga yang dikenali sebagai hadis "ummi" pula menafsirkan hadis "Umar yang agak berbeza dengan pendapat ulama seperti Ibn Hajar, al-Sarakhshi, Ibn 'Abidin, al-Qarafi, al-Ramli dan Ibn Taimiyyah. Al-Subkī menjelaskan bahawa hadis tersebut bukanlah mencegah dan mencela hisab yang dilakukan ahli falak.

Seterusnya, penulisan ini membawakan pendapat ulama seperti Shaikh Shakir, al-Qaraḍāwī, Sharaf Qudah sebagai contoh ulama yang memiliki pendapat yang selari dengan al-Subkī. Antara pendapat yang menarik daripada al-Subkī, beliau telah membahagikan imkān al-rukyah kepada lima kategori. Pendapat beliau ini dilihat telah dikembangkan bahawa pakar-pakar falak/astronomi kontemporari seperti Yallop, South African Astronomical Observatory (SAAO) dan Odeh pada zaman moden ini. Seterusnya, artikel ini menjelaskan konsep kriteria imkān al-rukyah yang diketengahkan oleh alSubkī sama ada kriteria kenampakan anak bulan sesuai sebagai penentu atau pembantu dalam penentuan awal bulan. Isu ini sering dilihat dalam konteks penentuan tarikh awal puasa dan hari raya di sebahagian negara-negara di nusantara, seperti Brunei Darussalam, Republik Indonesia, Malaysia dan Republik Singapura.

Negara-negara ini menggunakan kriteria kenampakan anak bulan yang sama, namun masih terdapat perbezaan dalam penentuan hari raya dan tarikh mula berpuasa. Negara-negara ini bernaung dalam kesatuan yang dikenali MABIMS (Pertemuan Tahunan Tidak Rasmi Menteri-Menteri Agama Negara Brunei Darussalam, Republik Indonesia, Malaysia dan Republik Singapura). Contohnya, pada 1 Ramadan 1440, Malaysia, Indonesia, dan Singapura berpuasa pada tarikh yang sama, iaitu pada 6 Mei 2019. ${ }^{14}$ Sedangkan negara Brunei walaupun berada dalam kesatuan yang sama menetapkan tarikh 1 Ramadan pada 7 Mel 2019. ${ }^{15}$ Justeru, dengan meneliti pendapat al-Subkī, ia boleh dijadikan panduan dalam menjelaskan isu perbezaan penentuan tarikh dalam kalendar Hijrah in di rantau ini.

14 Cnbc Indonesia, https://www.cnbcindonesia.com/news/20190505191032-470595/menteri-agama-1-ramadan-jatuh-pada-senin-6-mei-2019, dicapai pada 8 Mei 2019.

15 Sinar Harian, 'Brunei mula berpuasa Selasa,' https://www.sinarharian.com.my/ article/26703/GLOBAL/Brunei-mula-berpuasa-Selasa, dicapai pada 8 Mei 2019. 


\section{BIOGRAFI RINGKAS IMAM TAQĪ Al-DĪN Al-SUBKĪ}

Nama sebenar Imam Taqī al-Dīn al-Subkī adalah Abū al-Hasan Taq̄i al-Dīn 'Alī bin Abd al-Kafi al-Subkī. ${ }^{16}$ Gelaran al-Subkī diberikan bersempena salah satu nama perkampungan di Mesir, iaitu Sabak. ${ }^{17}$ Beliau merupakan seorang ulama yang menjadi rujukan umat Islam sewaktu zaman beliau disebabkan ketinggian ilmu dan kemuliaan akhlaknya sehingga digelar sebagai Sheikh al-Islam. ${ }^{18}$ Beliau dilahirkan di Sabak, Mesir pada tahun $683 \mathrm{H} / 1284 \mathrm{M}$ dan meninggal pada 756H/1355M di Kaherah, Mesir. ${ }^{19}$ Nama bapa al-Subkī adalah Zain al-Din Abū Muhammad Abd al-Kafi bin 'Alī bin Tamam al-Ansari alHazraji al-Subkī al-Misri atau lebih dikenali sebagai Syeikh Zain al-Din alSubkī. ${ }^{20}$

Sejak kecil, bapa al-Subkī membawa beliau ke Kaherah, Mesir untuk berguru dengan ulama seperti Syeikh Taqī al-Dīn Ibn Daqiq al-Eid. Sewaktu menimba ilmu di Kaherah, beliau dikenali sebagai seorang anak yang cerdas dan berdisiplin kerana beliau mampu menguasai pelbagai ilmu dalam masa yang singkat. ${ }^{21}$ Setelah al-Subkī mengikut bapanya berpindah ke Kaherah, Mesir beliau banyak berguru dengan beberapa orang ulama Mesir termasuklah Hafiz al-Dimyati dalam bidang hadis, Ibn Rif'a dalam bidang undang-undang dan al-'Iraqi dalam bidang al-Quran, Taj al-Din Ibn 'Ala atau dikenali sebagai Abū Hayyan dalam bidang balaghah. ${ }^{22}$ Setelah menguasai pelbagai cabang ilmu, al-Subkī dikenali sebagai pakar undang-undang, pakar pentafsir al-

16 Al-Ṣafdī, $A^{\prime}$ yàn al-'Asr wa A'wān al-Nașr, vol. 3, ed. 'Alī Abū Zayd et al. (Dimashq: t.p.,1998), 417.

17 'Alī Bashā Mubārak, Al-Khatat al-Tawfūqiyyah al-Jadīdah Li Miṣr al-Qāhirah, vol. 12 (Qāhirah: Maṭbā'ah Dār al-Kutub wa al-Wathā’iq al-Qawmiyyah, 2001), 18.

18 Nishtaman Bashīr Muḥammad, 'Al-Shaykh Taqī al-Dīn al-Subkī: Dirāsah 'An Duwarih fī al-Hayah al-Fikriyyah Wa al-Qaḍā'iyyah', Humanities Journal of University of Zakho, vol. 5, no. 3 (2017): 677.

19 Al-Ṣafdī, A'yān al- 'Asr wa A'wān al-Nașr, vol. 3, 417.

20 Al-Subkī, Tāj al-Dīn 'Abd al-Wahhāb bin Taqī al-Dīn al-Subkī, Tabaqāt alShāfi 'iyyah al-Kubrāa, vol. 1, ed. Mạ̣mūd Muhammad al-Thanah̄̄ dan 'Abd al-Fattāh Muḥammad al-Halwī (Qāhirah: Ḥijr li al-Ṭibā'ah wa al-Nashr wa alTawzī', 1976), 89.

21 Al-Dhahabī, al-A 'lām bi Wāfiyyat al-A 'lām, vol. 2, ed. Mustafā bin 'Alī bin 'Iwād dan Rabī' Abū Bakr 'Abd al-Baqī (Bayrūt: t.p., 1993), 479; Ibn Kathīr, Abū alFidā' Ismā 'īl bin 'Umar bin Kathīr al-Qurayshī al-Basrī al-Dimashqī, al-Bidāyah wa al-Nihāyah, vol. 14 (Qāhirah: Dār Iḥyā' al-Turāth al-'Arab̄ì, 2001), 26.

22 Al-Ṣafdī, A'yān al-'Asr wa A'wān al-Nașr, vol. 3, 424. 
Quran, pakar ilmu pemikiran, pakar ilmu falsafah, pakar ilmu mantik dan juga pakar dalam bidang balaghah. Selain itu, dalam beberapa tahun beliau berkhidmat sebagai professor dan tenaga pengajar di beberapa pusat pengajian yang terkenal di Kaherah seperti al-Manșūriyyā, al-Hakariyya dan al-Sifiyya. ${ }^{23}$

Pada tahun 739H/1338M, beliau telah menerima tawaran untuk menjadi ketua hakim di Damaskus, di samping menjawat jawatan sebagai seorang professor di pusat pengajian tinggi di Damaskus seperti al-Ghazzaliyya, al'Adiliyya, al-Atabakiyya, al-Manșūriyyā, al-Shamiyya al-Barraniyya dan alAshrafiyya. ${ }^{24}$ Setelah 17 tahun berkhidmat sebagai ketua hakim di Damaskus, kemudiannya beliau jatuh sakit dan jawatan tersebut telah digantikan oleh anak lelakinya iaitu Imam Taj al-Din al-Subkī. Walaupun anak lelaki al-Subkī dilantik menjadi ketua hakim di usia yang masih muda, namun beliau mampu menjalankan tugas sebagai ulama, hakim dan imam besar di Damaskus. Ia menunjukkan ketokohan dan kepimpinan anak lelaki al-Subkī walaupun ketika itu usianya masih muda, namun dapat menggalas tanggungjawab dengan baik. ${ }^{25}$

Al-Subkī juga merupakan seorang ulama besar Shafi'iyyah di Mesir dan menguasai pelbagai ilmu termasuklah ilmu fiqh, usul fiqh, ilmu hadis, ilmu tafsir, ilmu usuluddin, balaghah dan mahir bersyair. ${ }^{26}$ Beliau telah menghasilkan beberapa hasil karya dan penulisan seperti Takmilah Sharh Muhazzab, al-Ibtihāj fi Sharh al-Minhaj iaitu Sharh Kitāb Minhaj karangan Imam al-Nawawī, al-Durr al-Nazim fì Tafsìr al-Qur'ān al-'Azìm, al-Tahrīb Muhazzab fi Tahr al-Madhhab, iaitu Sharh Kitāb Minhaj karangan Imam alNawawī, Raf' al-Haj̄̄b An al-Mukhtasar Ibn al-Haj̄̄b, Nūr al-Mașābih fì Șalāh al-Tarāwīh, al-Raqm al-Ibrizī fì Sharh al-Mukhtasar Tibrizī iaitu Sharḥ Kitāb Mukhtasar Tibrizī, Sharh Miṣbah bih al-Sunnah iaitu karangan al-Baghawī dan kitab menolak fahaman Ibn Taymiyyah berkaitan talaq dan ziarah. ${ }^{27}$

23 Nishtaman Bashīr Muhammad, 'al-Shaykh Taq̄i al-Dīn al-Subkī: Dirāsah 'an Duwarih fĩ al-Hayah al-Fikriyyah wa al-Qaḍā'iyyah,' 679.

24 Al-Subkī, Tāj al-Dīn 'Abd al-Wahhāb bin Taqī al-Dīn al-Subkī, Tabaqāt alShäfi 'iyyah al-Kubrā, vol. 2, 75.

25 Al-Subkī, Tāj al-Dīn 'Abd al-Wahhāb bin Taqī al-Dīn al-Subkī, Tabaqāt alShäfi 'iyyah al-Kubrāa, vol. 1, 139-328.

26 Nishtaman Bashīr Muhammad, 'al-Shaykh Taq̄i al-Dīn al-Subkī: Dirāsah 'An Duwarih fĩ al-Hayah al-Fikriyyah wa al-Qaḍā'iyyah,' 679.

27 Al-Nahar, 'Umar Muhammad, 'Asr al-Mamālik al-Bahriyyah Dirāsah Fikriyyah, vol. 8 (Dimashq: Dār al-Nahụah li al-Tibā‘ah wa al-Nashr wa al-Tawzī‘, 2017), 107. 


\section{PERBAHASAN HADIS-HADIS RUKYAH DAN HISAB MENURUT Al- SUBKI}

Kenampakan anak bulan merupakan fenomena alam yang amat penting dan menjadi petanda bagi penentuan awal bulan Hijrah kususnya penentutigaan awal Ramadan dan Syawal. Tuntutan rukyah telah dilaksanakan bermula zaman Rasulullah SAW lagi sehingga kini. Pada asasnya, usaha untuk melihat anak bulan dilakukan pada akhir setiap bulan Hijrah iaitu pada 29 haribulan. Jika anak bulan kelihatan, maka keesokannya adalah 1 haribulan Hijrah. Sebaliknya, jika tidak kelihatan, anak bulan tersebut digenapkan menjadi 30 hari. Dalam menjelaskan metodologi penentuan awal Ramadan dan Syawal, al-Subkī telah mengemukakan tiga hadis utama.

Pertama:

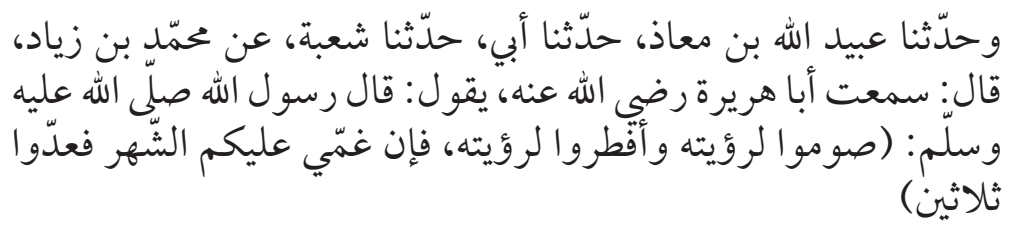

"Telah menceritakan kepada kami 'Ubayd Allāh bin Mu'adz, telah menceritakan kepada kami Abi, telah menceritakan kepada kami Shu'bah, dari Muhammad bin Ziyad, beliau berkata: Aku mendengar Abū Hurayrah RA berkata bahawa Rasulullah SAW bersabda: "Berpuasalah kamu apabila telah melihat anak bulan dan berbukalah apabila telah melihatnya. Jika pandangan kamu dilindungi oleh awan, maka hitunglah tiga puluh hari.” 28

Kedua:

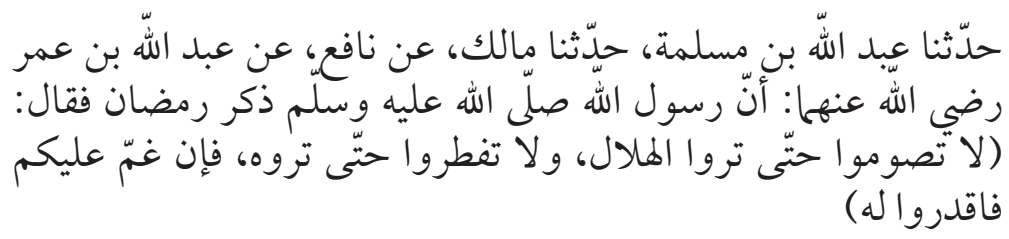

"Telah menceritakan kepada kami, 'Abd Allāh bin Maslamah, telah menceritakan kepada kami Malik, dari Nafi', dari 'Abd Allāh bin 'Umar RA bahawa Rasulullah SAW telah menceritakan tentang bulan Ramadhan lalu baginda bersabda: "Janganlah

${ }_{28}$ Hadis riwayat Muslim, Șạ̄ị Muslim, Bāb Wujūb Șawm Ramaḍān li Ru'yah alHilāl, no. hadis 1081/19. Lihat Abū al-Ḥusayn Muslim al-Ḥajjāj, Ṣaḥ̄h Muslim, vol. 2 (Bayrūt: Dār Ihyā’’ Turāth al-'Arab̄i, t.t.), 762. 
kalian berpuasa sehingga kalian melihat bulan dan jangan pula kalian berbuka sehingga kalian melihatnya. Apabila anak bulan terhalang oleh awan, maka kira-kirakanlah bilangannya (buatlah perhitungan hari baginya)." 29

Ketiga:

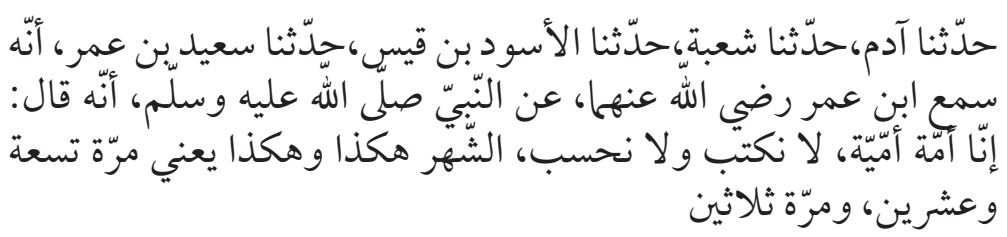

"Bahawa Ibn 'Umar RA telah mendengar, daripada Rasulullah SAW bahawa beliau telah bersabda: "Sesungguhnya umat yang buta huruf, tidak tahu menulis dan tidak tahu mengira, bulan adalah sekian sekian. Iaitu sesekali 29 hari dan sesekali lagi 30 hari." 30

Al-Subkī telah menjelaskan hadis pertama dari aspek tatabahasa Arab, menurut beliau huruf lam pada kalimah liru'yatihi adalah lam li ta'lil yang membawa maksud kerana atau justifikasi. ${ }^{31}$ Ini bermakna hukum berpuasa mesti berdasarkan kepada rukyah anak bulan. Perkataan ru'yatihi merupakan kalimah masdar yang disandarkan mudaf kepada maf'ul bih dan fa'il yang tidak dinyatakan dalam ayat ini. Justeru ayat ini bermkasud berpuasa hanya dikhususkan kerana atau sebab melihat anak bulan. Namun begitu, mengikut al-Subkī bukan semua manusia perlu melihat anak bulan tersebut. Dalam hal ini hanya orang-orang tertentu sahaja sudah memadai untuk melihat anak bulan dan tidak semestinya semua orang melihat anak bulan untuk berpuasa. ${ }^{32}$ Pendapat beliau selari dengan ulama hadis yang lain seperti al-'Asqalān̄ī ${ }^{33}$

29 Hadis riwayat al-Bukhārī, Șạ̄ị al-Bukhārī, Bāb Qawl al-Nabī SAW 'Sumu li Ru'yatih wa Iftir li Ru'yatih', no. hadis 1906. Lihat Abī ‘Abd Allāh Muhammad Ibn Ismā'il al-Bukhārī al-Ju'fì, Ṣah̄ịh al-Bukhārī, vol. 3 (Dimashq: Dār al-Ṭūq alNajāḥ, 2001), 27.

30 Hadis riwayat al-Bukhārī, Șah̄hh al-Bukhārī, Bāb Qawl Nabī SAW (La Naktub wa la Naḥsub), no. hadis 1908. Lihat Abī 'Abd Allāh Muḥammad Ibn Ismā'il alBukhārī al-Ju'fī, Șaḥīh al-Bukhārī, vol. 2 (Qāhirah: al-Maṭba'ah al-Salāfiyyah, 2001), 33.

31 Al-Subkī, Taqī al-Dīn 'Alī bin 'Abd al-Kāfì, Adillah fì Ithbāt al-Ahillah, ed. Samīrah Dāwud al-'Ānī (Bayrūt: Dār al-Fatḥ li al-Dirāsat wa al-Nashr, 2013), 146.

32 Al-Subkī, Taqī al-Dīn 'Alī bin 'Abd al-Kāfì, Adillah fì Ithbāt al-Ahillah, 146.

33 Aḥmad Ibn 'Alī Ibn Ḥajar al-'Asqalān̄i, Fatḥ al-Bārī (Riyāụ: Maktabah al-Mālik Fahd al-Wațāniyyah, 2001), 142. 


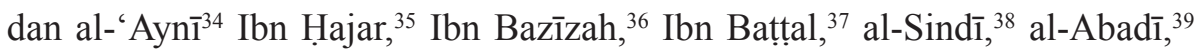
al-Nawawī ${ }^{40}$ al-'Aynī ${ }^{41}$ dan al-Qastalānī ${ }^{42}$ yang menyatakan penentuan awal bulan perlu didasarkan kepada rukyah anak bulan dan sekiranya anak bulan tidak kelihatan perlulah digenapkan Shaaban kepada 30 hari dalam menyampaikan makna dalam konteks hadis ini.

Manakala dalam menafsirkan hadis yang kedua, al-Subkī memfokuskan kepada kalimah faqdurulah, dengan membawakan tiga pendapat para ulama. Pertama, perlunya untuk melengkapkan tempoh 30 hari pada bulan Shaaban, sepertimana pada pandangan beliau telah dinyatakan secara jelas dalam hadis pertama dalam kitab Șah̄ị al-Bukhārī. Kedua, pendapat yang mengatakan ditadkirkan dengan penggunaan hisab ahli falak. Ketiga, al-Subkī membawakan pentafsiran dalam kalangan ulama Hanabilah yang bermaksud sempitkan. ${ }^{43}$ Ia dilihat selari dengan pendapat Matraf Ibn 'Abd Allah, Abū al-'Abbas Ibn Suraij dan Ibn Qutaybah ${ }^{44}$ yang menakrifkan daiyiqulah dengan berpandukan kepada hisab pergerakan fasa-fasa bulan. ${ }^{45}$ Ini bermaksud sekiranya anak bulan tidak kelihatan pada 29 Shaaban kerana faktor cuaca yang tidak mengizinkan, maka umat Islam dibolehkan berpuasa keesokan harinya. Hal ini kerana ulama

34 Al-'Aynī, Badr al-Dīn Abī Muhammad Maḥmūd bin Aḥmad, 'Umdah al-Qārī Sharḥ Sahīh al-Bukhārī, vol. 10 (Bayrūt: Dār al-Kutub al-'Ilmiyyah, 2001), 388.

35 Aḥmad Ibn 'Alī Ibn Ḥajar al-'Asqalān̄̄, Fatḥ al-Bārī, 127.

36 Aḥmad Ibn 'Alī Ibn Hajar al-'Asqalānī, Fath al-Bārī, 127.

37 Abū al-Ḥasan 'Alī bin Khalf bin 'Abd al-Mālik bin Bațtal al-Kubrā al-Qurțubī, Sharh Saḥ̄ḥ al-Bukhārī (Riyāḍ: Maktabah al-Rushd, 2003), 31.

38 Nūr al-Dīn bin 'Abd al-Hādī Abū al-Hasan al-Sindī, Hāshiyah al-Sindi 'ala alNasā 'î, vol. 4 (Ḥalab: Maktabah al-Maṭba'ah al-Islāmiyyah, 1986), 139.

39 Abī al-Ṭayyib Muḥammad Shams al-Dīn al-Ḥaq al-'Aẓīm Abadī, Sharh Sunan Abī Dāwud (Madīnah: al-Maktabah al-Salafiyyah, 1967), 310.

40 Muḥy al-Dīn Abū Zakariyyā bin Yahyā Sharf al-Nawawī, Minhāj Sharḥ Muslim al-Hajjāj, vol. 7 (Qāhirah: Matba'ah Mișriyyah, 1980), 189.

41 Al-'Aynī, Badr al-Dīn Abī Muḥammad Maḥmūd bin Aḥmad, 'Umdah al-Qārī Sharḥ Sah̄ih al-Bukhārī, 307.

42 Al-Qastalānī, Aḥmad bin Muḥammad, Irshād al-Sārī Sharḥ Ṣaḥịh al-Bukhārī, vol. 3 (Qāhirah: Dār al-Ṭabā'ah Maqsriyyah, 1980), 359.

43 Al-Subkī, Taqī al-Dīn 'Alī bin 'Abd al-Kāfì, Adillah fì Ithbāt al-Ahillah, 145.

44 Yūsuf al-Qaraḍāwī, Fiqh al-Siyām (Qāhirah: Maktabah al-Wahbah, t.t.), 26.

45 Muhy al-Dīn Abū Zakariyyā bin Yahyā Sharf al-Nawawī, Minhāj Sharh Muslim al-Hajjāj, 189; Al-'Ayn̄̄, Badr al-Dīn Ab̄̄ Muḥammad Mạ̣mūd bin Aḥmad, 'Umdah al-Qārī Sharh Saḥ̄h al-Bukhārī, 387; Al-Sayūṭī, 'Abd al-Raḥmān bin Abī Bakr, al-Dibāj 'ala Șaḥịh Muslim al-Hajjāj, vol. 3 (Riyāḍ: Dār Ibn 'Affān li Nashr wa al-Tawzī', 1995), 183. 
berpendapat bahawa makna kalimah faqdurulah bermaksud daiyiqulah iaitu perlu dikira kedudukan anak bulan pada hari tersebut. ${ }^{46}$ Walau bagaimanapun, al-Subkī bertegas mengatakan penafsiran yang pertama iaitu sekiranya anak bulan tidak kelihatan pada 29 Shaaban, maka dengan lengkapkan bilangan bulan kepada 30 hari adalah pendapat yang paling tepat. ${ }^{47}$

Seterusnya terdapat persamaan di antara hadis pertama dan hadis yang kedua. Kedua-dua hadis di atas menunjukkan bahawa perlu mengambil kira sebab utama wajib berpuasa iaitu kerana melihat anak bulan. Ini menunjukkan bahawa tidak boleh diterima pendapat yang mengatakan bahawa tidak disyaratkan untuk melihat anak bulan, namun hanya memadai dengan wujud anak bulan yang dikenali sebagai wujūd al-hiläl untuk memulakan bulan yang baharu. Bagi al-Subkī, bukan sahaja wujūd al-hiläl tidak memadai, malah perlunya mengambil kira keadaan dan kedudukan anak bulan boleh kelihatan (imkān al-rukyah) atau tidak kelihatan untuk memulakan bulan yang baharu. ${ }^{48}$ Lantaran itu, menurut pendapat al-Subkī dapat dijelaskan bahawa beliau menerima konsep imkān al-rukyah dan menolak wujūd al-hilāl.$^{49}$ Dengan erti kata lain, sekiranya anak bulan berada di atas ufuk (wujūd al-hilāl) pada 29 Shaaban, namun kedudukan anak bulan tersebut belum cukup syarat untuk kelihatan kerana tidak imkān al-rukyah maka dikira keesokan harinya sebagai 30 Shaaban.

Dalam konteks ulama kontempori, al-Qaraḍāwī dan Sharaf Qudah bersama dengan al-Subkī, khususnya dalam penerimaan konsep imkān al-rukyah. Dalam hal itu, al-Qaraḍāwī telah berpendapat anak bulan mesti berada di atas ufuk selepas matahari terbenam yang memungkinkan anak bulan kelihatan dengan mata kasar, seperti 15 atau 20 minit yang dirumuskan oleh ahlinya ( $a h l$ al-ikhtisas). ${ }^{50}$ Berdasarkan kenyataan al-Qaraḍāwī tersebut, dapat disimpulkan bahawa bukan sahaja perlu dipastikan anak bulan wujud di atas ufuk semasa hari cerapan, malah perlu ditambah dengan kriteria tambahan yang lain. Pada masa yang sama juga, Sharaf Qudah berpendapat kriteria imkān al-rukyah boleh dijadikan pengesah atau pun penafi berdasarkan hadis-hadis yang telah jelas tidak melarang untuk menggunakan kedua-duanya sekali. ${ }^{51}$ Beliau juga

\footnotetext{
46 Al-Sayūṭị, 'Abd al-Raḥmān bin Abī Bakr, al-Dibāj 'ala Ṣahīh Muslim al-Hajjājj, vol. 3, 183.

47 Al-Subkī, Taqī al-Dīn 'Alī bin 'Abd al-Kāfì, Adillah fì Ithbàt al-Ahillah, 145.

48 Al-Subkī, Taqī al-Dīn 'Alī bin 'Abd al-Kāfì, Adillah fì Ithbāt al-Ahillah, 146.

49 Al-Subkī, Taqī al-Dīn 'Alī bin 'Abd al-Kāfì, Adillah fì Ithbāt al-Ahillah, 146.

50 Yūsuf al-Qaraḍāwī, Kayf Nata 'amal ma 'a al-Sunnah al-Nabawiyyah (Qāhirah: Dār al-Shuruq, 2005), 169.

51 Sharf Qudah, 'Thubūt al-Shahr al-Qamarī Bayna al-Ḥadīth al-Nabawī wa 'Ilm alHadīth,' Majallah al-Dirāsah Jāmi 'ah Urdūn, vol. 26, no. 2 (1999): 13.
} 
membawakan dua pendapat ulama untuk menyokong pendapat beliau iaitu pertama, Mușțafā al-Marāghī dan kedua, 'Alī al-Ṭanțawī. Mengikut Mușțafā al-Marāghī yang berpandangan kesaksian pemerhati perlu ditolak sekiranya hisab boleh membuktikan bahawa anak bulan itu tidak mungkin dapat dilihat. ${ }^{52}$ Begitu juga dengan 'Alī al-Ṭanțawī yang berpendapat bahawa hisab merupakan qat' $\bar{l}$ sebagai penafi sedangkan kesaksian atas rukyah itu tidak qat ‘' (ghayr qat 'iyyah). Tambahan pula, kesaksian itu dibuat oleh saksi yang diragui ataupun pendusta. ${ }^{53}$ Dari kenyataan berikut, dapat disimpulkan bahawa ulama berkenaan menerima kriteria imkān al-rukyah dalam menentukan awal bulan Hijrah.

Seterusnya dalam menafsirkan hadis yang ketiga, al-Subkī menjelaskan bahawa hadis tersebut jelas menunjukkan bahawa tempoh hari dalam sebulan sama ada 29 ataupun 30 hari. Al-Subkī juga telah menegaskan bahawa hadis di atas bukanlah secara spesifik merujuk kepada tidak boleh diterima pendapat ahli nujum/falak yang mengatakan tempoh sebulan dipisahkan dengan ijtimak ${ }^{54}$ ke ijtimak seterusnya. ${ }^{55}$ Kemudiannya menurut ahli falak/nujum ada ketikanya keadaan di mana kemungkinan anak bulan kelihatan dan ada ketikanya anak bulan tidak kelihatan. ${ }^{56}$ Justeru, jelas bagi al-Subkī bahawa hadis ini bukanlah mencegah atau mencela perbuatan mengira atau menulis, bahkan perbuatan mengira dan menulis disuruh sama sekali oleh baginda Nabi Muhammad SAW. Mengikut ulama selepas beliau iaitu Ahmad Muhammad Shakir, semasa zaman pra-Islam dan semasa zaman awal Islam tidak dapat diragui bahawa masyarakat Arab tidak mempunyai pengetahuan saintifik (ma'rifah 'ilmiyyah jazimah) tentang ilmu astronomi. Mereka merupakan umat yang

52 Aḥmad Muhammad Shakīr, Awā'il al-Shuhūr al- 'Arabiyyah: Hal Yajūz Shar 'an Ithbātuha bi al-Hisāab al-Falakī? (Qāhirah: Maktabah Ibn Taymiyyah, 1937), 15.

53 Mujahid Ma'mun Diraniyyah, al-Fatawā 'Al̄̄ al-Ṭantawī, vol. 2 (Jeddah: Dār alManārah, 1986), 222-224; Sharf Qudah, 'Thubūt al-Shahr al-Qamarī Bayna alHadīth al-Nabawī wa 'Ilm al-Hadīth,' 13.

54 Ijtimak merupakan fenomena bulan dan matahari berada pada satah yang sama. Kelahiran bulan baru (new moon) dikira pada fenomena ijtimak. Anak bulan tidak boleh kelihatan semasa cerapan anak bulan dilakukan pada hari ke 29 Hijrah sekiranya ijtimak belum berlaku. Ini disebabkan oleh anak bulan dikira belum wujud atau belum lahir.

55 Al-Subkī, Taqī al-Dīn 'Alī bin 'Abd al-Kāfì, Adillah fì Ithbāt al-Ahillah, 147; 'Imād 'Abd 'Az̄̄z Mujahid, Dalīl al-Muslim al-Falakī ('Ammān: Dār Hunayn, 1994), 65; Muhammad Shawkah 'Audah, 'al-Farq Bayn al-Hilāl wa Tawallad al-Hilāl', (Makalah Islamic Cescent's Observation Project (ICOP), http://www. icoproject.org/paper.html, dicapai pada 2 April 2019.

56 Al-Subkī, Taqī al-Dīn 'Alī bin 'Abd al-Kāfì, Adillah fì Ithbāt al-Ahillah, 147. 
buta huruf kerana menulis dan mengira bukanlah menjadi sebahagian budaya lazim mereka. Adapun sesiapa yang mengetahui astronomi pada masa itu hanyalah memahami perkara asas yang diperoleh melalui cerapan dan secara tradisi lisan. Pengetahuan mereka tentang astronomi tidak berdasarkan kepada peraturan matematik dan bukti empirikal (barahin qat 'iyyah). Dengan alasan inilah Rasulullah SAW menetapkan kalendar Hijrah sebagai asas kepada ibadah dengan ciri-cirinya yang pasti dan boleh dicapai oleh hampir semua orang, iaitu dengan melihat anak bulan dengan menggunakan mata kasar. Ia merupakan piawaian yang terbaik dan ukuran paling tepat untuk menentukan kitaran waktu dan amalan-amalan agama, ${ }^{57}$ sepertimana dalam firman Allah SWT di dalam al-Quran:

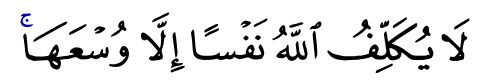

"Allah tidak memberati seseorang melainkan apa yang terdaya olehnya."

(Surah al-Baqarah, 2: 286)

Justeru, ia akan menjadi tidak konsisten dengan kebijaksanaan Ilahi untuk membuat hisab sebagai (manat al-ithbat) dalam isu kenampakan anak bulan. Syarat-syarat untuk menggunakan hisab akan menjadi beban yang memberatkan. Hanya sebahagian daripada mereka iaitu masyarakat luar bandar yang akan menerima maklumat tersebut jika orang dari bandar memberitahu kepada mereka secara lisan. Kebanyakan masyarakat Arab di luar bandar lambat menerima maklumat dari bandar. Bahkan orang-orang bandar mengikut pendapat pakar dalam astronomi pada masa itu, kebanyakan dari mereka adalah ahli kitab ${ }^{58}$ dari agama Yahudi dan Kristian. ${ }^{59}$ Setelah orang Islam mula menakluk dunia, mereka juga mula menguasai ilmu pengetahuan dan memberi sumbangan dalam setiap disiplin ilmu. Mereka menterjemahkan dan menguasai ( 'ulūm al-awā'il), membongkar banyak rahsia dan kemudiannya untuk disampaikan kepada masyarakat yang akan datang. Di antara ilmu ini ialah ilmu astronomi, astrologi dan mengukur jarak antara bintang. ${ }^{60}$ Oleh yang demikan, kini terdapat cara lain yang lebih tepat kepada maksud hadis tersebut yang dapat mengelakkan berlakunya kesilapan dan pendustaan untuk mengetahui awal bulan serta merupakan cara yang mudah dan senang

57 Aḥmad Muḥammad Shakīr, Awā'il al-Shuhūr al-'Arabiyyah: Hal Yajūz Shar 'an Ithbātuha bi al-Hisāb al-Falakī?, 8.

58 Moosa, Ebrahim, 'Shaykh Ahmad Shākir and the Adoption of A Scientifically Based Lunar Calendar', Islamic Law and Society, no. 5 (1998): 73.

59 Aḥmad Muḥammad Shakīr, Awā'il al-Shuhūr al-'Arabiyyah: Hal Yajūz Shar 'an Ithbātuha bi al-Hisāb al-Falakī?, 8.

60 Aḥmad Muhammad Shakīr, Awā'il al-Shuhūr al-'Arabiyyah: Hal Yajūz Shar'an Ithbātuha bi al-Hisāb al-Falakī?, 8. 
didapati dan masih dalam keupayaan umat Islam, kerana terdapat pakar ilmu Astronomi, Geografi dan Fizik. Ilmu tersebut kini sudah sampai ke tahap global di mana pada zaman ini manusia telah sampai ke bulan dan telah membuat penyelidikan mengenainya. Maka ia perlu bergerak dengan cara baru (iaitu hisab) untuk mencapai matlamat yang dituntut oleh hadis. ${ }^{61}$ Menurut Ahmad Muhammad Shakir lagi, adalah wajib menetapkan awal bulan dengan hisab (wujūb ithbāt al-ahillah bi al-hisāb) dalam segala keadaan, kecuali dalam kes orang yang sukar untuk mendapatkan ilmu pengetahuan seperti sains. ${ }^{62}$ Beliau menegaskan bahawa hukum berubah dengan perubahan keadaan yang mempengaruhi orang-orang yang diwajibkan untuk mengamati ajaran agama (ikhtilāf al-ḥukm bi ikhtilāf aḥwāl al-mukallafin). ${ }^{63}$

Seterusnya Muhammad Shakir berpendapat, perintah supaya bergantung kepada rukyah sebagai 'illah yang berdasarkan nas "Kami umat yang buta huruf tidak tahu menulis dan mengira". Hukum itu bergantung kepada wujud atau tidak sesuatu 'illah. Oleh itu, apabila masyarakat telah keluar daripada keadaan buta huruf dan mendapat kemahiran menulis dan mengira yang kebanyakannya termasuk pakar dan orang awam mampu mencapai hisab yang bersifat (yaqin) dan (qat ' $\vec{\imath})$ dalam penentuan anak bulan. Maka mereka boleh bergantung kepada hisab yang sudah semestinya kaedah yang lebih baik. Apabila majoriti boleh mengira maka penyebab hukum ( 'illah) iaitu buta huruf akan hilang. Maka adalah menjadi kewajipan untuk mencari kaedah lain yang lebih pasti iaitu (al-yaqin al-thäbit). Oleh itu, adalah menjadi kewajipan untuk menerima kaedah hisab dalam penentuan awal bulan (ithbät al-ahillah) melalui maklumat yang boleh dipercayai daripada orang yang pakar dalam hisab. Masyarakat seharusnya menggunakan rukyah anak bulan kecuali apabila pengetahuan tentang hisab menjadi sukar, seperti dalam contoh di mana kawasan luar bandar yang terpencil dan kampung-kampung tidak dapat menerima maklumat. Secara jelasnya, jika maklumat tersebut mudah diterima maka adalah perlu untuk menggunakan hisab disebabkan hilang sebab hukum ( 'illah) tersebut, maka wajiblah juga untuk membangunkan hisab yang betul dari pusingan lengkap fasa-fasa bulan (al-ḥisāb al-haqiqī li al-ahillah). ${ }^{64}$

${ }^{61}$ Yūsuf al-Qaraḍāwī, Kayf Nata 'amal Ma'a al-Sunnah al-Nabawiyyah, 166.

62 Moosa, Ebrahim, 'Shaykh Ahmad Shākir and the Adoption of A Scientifically Based Lunar Calendar', 78.

63 Ahmad Muhammad Shakīr, Awā'il al-Shuhūr al-'Arabiyyah: Hal Yajūz Shar'an Ithbātuha bi al-Hisāb al-Falakī?, 15.

64 Moosa, Ebrahim, 'Shaykh Ahmad Shākir and the Adoption of A Scientifically Based Lunar Calendar', 77. 
Dalam konteks ulama kontemporari, pandangan al-Subkī ini diterima oleh ulama seperti ulama seperti al-Qaraḍāwī dan Sharaf Qudah. Bagi Yūsuf alQaraḍāwī, hadis-hadis tersebut menunjukkan matlamat dan menentukan wasilah. Matlamat hadis adalah jelas iaitu supaya orang-orang Islam berpuasa sepanjang bulan Ramadan bukannya berpuasa pada bulan yang lain, sama ada dalam bulan Shaaban atau Syawal. Baginda telah juga menunjukkan cara atau wasilah masuknya satu bulan dengan akhirnya satu bulan dengan perkara yang boleh difahami oleh orang awam dan tidak menyusahkan mereka. Yūsuf alQarađ̣āwī mengemukakan hujah bahawa, fatwa berubah disebabkan perubahan masa, tempat dan zaman. Menurutnya, hadis yang dijadikan hujah untuk tidak merujuk kepada ahli hisab itu kurang tepat kerana ia membicarakan perihal umat ketika zaman Rasulullah SAW sedangkan (ummi) bukan sesuatu yang tetap yang dikehendaki oleh Rasulullah SAW.

Baginda SAW telah berusaha keras untuk menanganinya dengan mengajar membaca dan menulis. Ia dimulai sejak perang Badar di mana pada peperangan tersebut, Rasulullah SAW telah berijtihad dengan mengambil kira pendapat Abū Bakar RA untuk menjadikan tebusan perang sebagai guru yang mengajar menulis dan membaca. ${ }^{65}$ Penerimaan hisab bagi mengetahui masuknya satu bulan perlu dilihat dari sudut qiyas awlawi. Hadis didatangkan dengan mensyariatkan cara yang lebih rendah, kerana itu masih mengandungi syak dan kemungkinan, iaitu cara rukyah. Tetapi Syariah tidak sekali-kali menolak cara yang lebih tinggi dan lebih sempurna untuk mencapai tujuan atau maksud tersebut. Cara yang membawa kepada persamaan dari sudut ibadah dan menunaikan lambang Islam (syi'ar) yang berkaitan dengan agama serta berhubung rapat dengan kehidupan dan kerohanian. Cara itu adalah dengan menggunakan hisab yang diyakini benar. ${ }^{66}$

Begitu juga dengan Sharaf Qudah yang menafsir hadis ketiga ini dengan pemahaman bahawa hadis ini berbentuk penafian dan ingin membuang kesulitan sekiranya masyarakat pada ketika itu disuruh menggunakan hisab dalam penentuan awal bulan. Hadis ini tidak sama sekali membawa maksud tegahan (al-nahy). Apa yang perlu difahami di sini, maksud hadis ini adalah menafikan bahawasanya keadaan umat Islam pada ketika itu umat yang maju ilmu sains amnya dan ilmu astronomi khasnya. Walau bagaimanapun, hadis ini tidak menegah dari mendalami ilmu hisab. Jika hadis ini difahami dengan makna tegahan terbuktilah hadis ini membawa kepada makna larangan penggunaan ilmu hisab termasuklah ilmu matematik dan ilmu yang mengira pergerakan cakerawala (ilmu astronomi) secara khasnya. Sebaliknya fahaman

65 Yūsuf al-Qaraḍāwī, Fiqh al-Siyām, 26.

66 Yūsuf al-Qaraḍāwī, Kayf Nata 'amal Ma 'a al-Sunnah al-Nabawiyyah, 166. 
seperti ini tidak pernah pun dinyatakan oleh mana-mana ulama. Bahkan jika difahami terdapat larangan berkaitan pembelajaran ilmu hisab secara tidak langsung ia juga membawa kepada larangan kedua iaitu tegahan belajar menulis. Hal ini kerana hadis ini juga mengaitkan "la naktub". Kenyataan ini juga tidak pernah dikeluarkan oleh ulama dan ianya bercanggah dengan semua ayat-ayat al-Quran dan hadis yang mana menyeru umatnya ke arah mencari ilmu pengetahuan tanpa ada pengecualian. ${ }^{67}$

\section{KRITERIA KENAMPAKAN ANAK BULAN (IMK $\left.\bar{A} N A L-R U^{\prime} Y A H\right)$}

Menurut al-Subkī, dalam penentuan awal bulan Hijrah perkara pokok yang perlu difahami adalah berkaitan peredaran fasa bulan dan pergerakkan matahari. Seterusnya, ketinggian anak bulan dari ufuk (qaus al-rukyah) ${ }^{68}$ yang dikenali sebagai altitud. ${ }^{69}$ Altitud merupakan jarak sudut antara ufuk dan anak bulan. Seterusnya al-Subkī menyebut (qus al-nur) ${ }^{70}$ yang merujuk pada sudut elongasi seperti yang ditunjuukan pada Rajah 1. Manakala, sudut elongasi pula ditakrifkan sebagai jarak sudut antara matahari dan anak bulan. ${ }^{71}$ Selain itu, al-Subkī juga menyebut (qaus al-makh) iaitu sela masa antara bulan terbenam dan matahari terbenam. ${ }^{72}$ Dalam ilmu sains kenampakan anak bulan dikenali sebagai (lag time).$^{73} \mathrm{Al}$-Subkī telah memetik pendapat ahli astronomi yang mengatakan anak bulan kelihatan tidak kelihatan sekiranya (qaus alrukyah) sebanyak $6^{\circ}$. Manakala, (qus al-nur) pula $9^{\circ}$ dan (qaus al-makh) pula $9^{\circ}$. Namun begitu, anak bulan akan mungkin kelihatan sekiranya melebihi bertambah darjah-darjah tersebut. ${ }^{74}$

${ }^{67}$ Sharf Qudah, 'Thubūt al-Shahr al-Qamarī Bayna al-Ḥadīth al-Nabawī wa 'Ilm alHadīth,' 5.

68 Al-Subkī, Taqī al-Dīn 'Alī bin 'Abd al-Kāfì, Adillah fì Ithbāt al-Ahillah, 118.

69 Odeh, Mohammad Shaukat, 'New Criterion for Lunar Crescent Visibility', Experimental Astronomy, 18 (2004), 41.

70 Al-Subkī, Taqī al-Dīn 'Alī bin 'Abd al-Kāfī, Adillah fì Ithbāt al-Ahillah, 118.

71 Odeh, Mohammad Shaukat, 'New Criterion for Lunar Crescent Visibility,' 41.

72 Al-Subkī, Taqī al-Dīn 'Alī bin 'Abd al-Kāfī, Adillah fì Ithbāt al-Ahillah, 118.

73 Odeh, Mohammad Shaukat, 'New Criterion for Lunar Crescent Visibility,' 41.

74 Al-Subkī, Taqī al-Dīn 'Alī bin 'Abd al-Kāfì, Adillah fì Ithbāt al-Ahillah, 118. 
Rajah 1: Antara Parameter yang Digunakan oleh al-Subkī dalam Penetapan Kriteria Kenampakan Anak Bulan

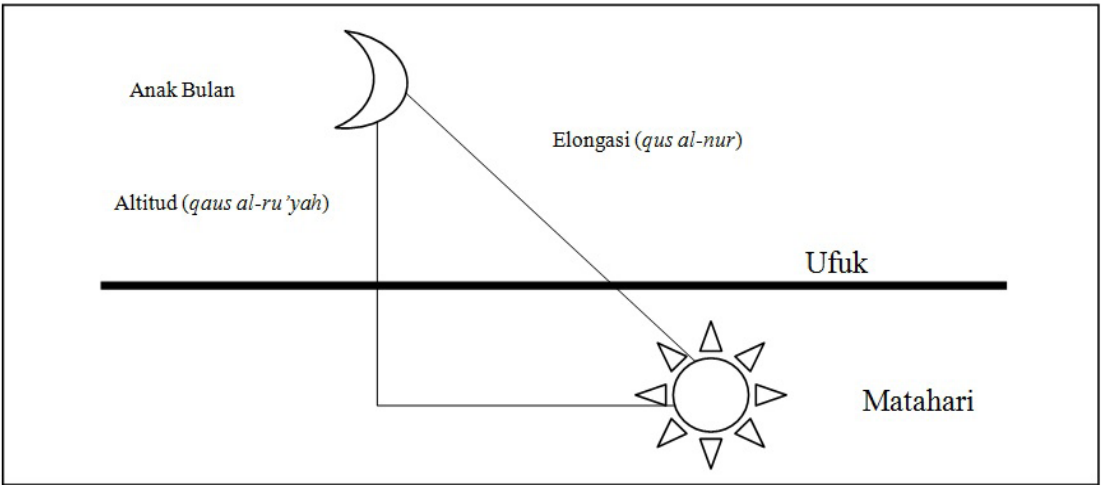

Sumber: Lakaran penulis

Penentuan kenampakan anak bulan (possibility of sighting) pada hari tertentu selepas berlakunya ijtimak bulan matahari dan bumi agak rumit kerana melibatkan beberapa faktor seperti kedudukan bulan dan dan matahari relatif pada ufuk tempatan, ${ }^{75}$ relatif kecerahan anak bulan berbanding kecerahan langit, dan faktor kecerahan atmosfera. ${ }^{76}$ Bagi ahli astronomi, ia adalah menjadi satu cabaran untuk melihat bulan yang paling kecil kerana ia bukan sahaja melibatkan astronomi, malah faktor meteorologi dan psikologi juga perlu diambil kira. ${ }^{77}$ Al-Subkī dilihat juga menyedari hal ini berdasarkan kenyataan beliau iaitu faktor lain yang mempengaruhi kenampakan adalah pencemaran udara dan kejernihanya, pembentukan anak bulan dari arah utara atau selatan, perbezaan kedudukan bulan terbit dan terbenam serta perbezaan kedudukan bintang terbit dan terbenam perlu diperhatikan dalam situasi ini.

Sepanjang sejarah, telah banyak percubaaan dibuat untuk mengemukakan kriteria kenampakan anak bulan. Ahli-ahli astronomi/falak menggunakan sama ada pendekatan empirikal dan teoritikal. Kaedah empirikal selalunya digunakan oleh ahli astronomi/falak dalam merumuskan kriteria kenampakan. Kaedah ini berdasarkan analisis kepada data-data kenampakan anak bulan yang telah dicerap dan dirumuskan satu kriteria kenampakan yang sesuai. Manakala, kaedah teoritikal pula digunakan untuk menyelesaikan masalah dengan melihat banyak faktor yang mempengaruhi kenampakan anak bulan

75 King D.A., 'Astronomy in the Service of Islam,' in Handbook of Archaeoastronomy and Ethnoastronomy, ed. Ruggles C. (New York: Springer, 2015), 185.

76 King, David A., 'Ibn Yūnus on Lunar Crescent Visibility', Journal For The History of Astronomy, vol. 19 (1988): 155-168.

77 Kordi, Ayman S., 'The Psychological Effect on Sightings of The New Moon,' 219222; Schaefer, Bradley E., 'Visibility of the Lunar Crescent,' 511. 
dan seterusnya membangunkan model matematik yang deskriptif. ${ }^{78}$ Usaha untuk membangunkan kriteria kenampakan ini bermula sejak zaman Babylion lagi yang menggunakan keadah empirikal. ${ }^{79}$ Seterusnya, usaha membangunkan kriteria kenampakan anak bulan dengan kaedah teoritikal diteruskan oleh ilmuan Islam. ${ }^{80}$ Banyak ahli astronomi Islam telah membangunkan kriteria kenampakan anak bulan sendiri seperti Ibn Țāriq, Habash, al-Khawarizmī, al-Khazin, al-Ṭabarī, al-Fahd, al-Farghan̄̄, Thabit Ibn Qurrah, al-Battan̄̄, Ibn Maymun, al-Birūn̄̄, al-Șufī, Ibn Sina, al-Ṭūsī and al-Kashan̄̄ ${ }^{81}$ Pada abad ke 20, pembangunan kriteria kenampakan anak bulan telah diberi perhatian oleh ahli astronomi Muslim mahupun bukan Islam. Ini dapat dilihat seperti kriteria yang dihasilkan oleh Fotheringham, Maunder, Danjon, Bruin, Ilyas, Schaefer, Yallop, Caldwell and Laney, Odeh dan Amir. ${ }^{82}$

Berdasarkan kriteria yang dikemukakan oleh al-Subkī, didapati beliau telah merujuk kepada tiga kriteria utama iaitu lag time, elongasi dan altitud. Kriteria lag time mula diperhatikan semasa zaman Babylion. Mereka merumuskan anak bulan akan kelihatan apabila sela masa anak bulan terbit dan terbenam adalah 48 minit $\left(12^{\circ}\right) .{ }^{83}$ Seterunya Ilyas mengkiritik kriteria ini perlu diberikan dengan dikaitakan dengan musim dan latitud. Untuk tujuan itu, Ilyas membahagikan kepada tiga jenis latitud iaitu rendah, pertengahan dan tinggi. Bagi latitud rendah, $0^{\circ}$ nilai lag time yang sesuai adalah melebihi 41 minit. Manakala pada latitud pertengahan $30^{\circ}$ nilai lag time yang sesuai adalah 46 minit. Seterusnya pada latitud 40 nilai lag time perlulah melebihi 49 minit. Manakala pada latitud tinggi $50^{\circ}$, nilai lag time yang sesuai adalah melebihi 55 minit. ${ }^{84}$ Seterusnya Odeh telah merumuskan dari 737 data kenampakan anak bulan didapati nilai lag time yang paling minimum untuk anak bulan

78 Fatoohi, Louay J., Stephenson, F. Richard \& Al-Dargazelli, Shetha S., 'The Babylonian First Visibility of the Lunar Crescent: Data and Criterion,' Journal for the History of Astronomy, vol. 30 (1999): 51-72.

79 Sultan, Abdul Haq, 'First Visibility of the Lunar Crescent: Beyond Danjon's Limit', The Observatory, vol. 127 (2007): 53-59.

80 Mohammad Ilyas, 'Lunar Crescent Visibility Criterion and Islamic Calendar', Quarterly Journal of the Royal Astronomical Society, vol. 35 (1994): 425-461.

81 Schaefer, Bradley E., 'Lunar Crescent Visibility', Quarterly Journal of the Royal Astronomical Society, vol. 37 (1996): 759-768; Mohammad Ilyas, 'Lunar Crescent Visibility Criterion and Islamic Calendar', 425-461.

82 Hasanzadeh,Amir, 'Study ofDanjonLimitinMoonCrescentSighting', Astrophysics and Space Science, vol. 339 (2012): 211-221.

83 Mohammad Ilyas, 'Lunar Crescent Visibility Criterion and Islamic Calendar', 425-461.

84 Muhammad Ilyas, Sistem Kalendar Islam dari Perspektif Astronomi, 103. 
kelihatan adalah dengan sela masa minimum untuk bulan sabit adalah 21 minit menggunakan alat optik dan 29 minit menggunakan mata kasar. Namun begitu, rekod terbaru menunujukkan bahawa lag time 20 minit anak bulan telah kelihatan di negara Iran. ${ }^{85}$

Seterusnya, al-Subkī juga telah menyebut mengenai kriteria elongasi. Dalam kajian moden, kriteria ini mula diperhatikan oleh André Danjon. ${ }^{86}$ Danjon telah mengukur 75 sampel bulan yang dicerap dengan menggunakan pendekatan teoritikal. Hasil kajian Danjon pada kedudukan anak bulan belum mencapai $7^{\circ}$, elongasi anak bulan tidak boleh kelihatan. ${ }^{87}$ Seterusnya McNally menggunakan pendekatan teoritikal telah merumuskan ${ }^{88} 5^{\circ}$ had elongasi dan bukannya $7^{\circ} .^{89}$ Schaefer telah membangunkan kriteria menggunakan kedah teoritikal dan merumuskan bahawa kriteria $7^{\circ}$ sebagai had limit untuk anak bulan kelihatan. Di samping itu, Ilyas menyatakan bahawa had elongasi $7^{\circ}$ hanya untuk panduan umum sahaja. Namun, untuk tujuan pembentukan kalendar had elongasi $10.5^{\circ}$ adalah yang terbaik. ${ }^{90}$ Fatoohi et al. mengambil kira hasil cerapan kuno dan moden sebanyak 295 data moden telah dikumpulkan dan merumuskan nilai elongasi yang sesuai bagi anak bulan kelihatan adalah $7.5^{\circ}$. Setelah itu, Odeh telah berjaya mengumpulkan 737 data. Daripada jumlah keseluruhan data tersebut, Odeh telah mendapati $6.4^{\circ}$ adalah had sempadan elongasi bagi mata kasar dan $7.7^{\circ}$ bagi peralatan optik. ${ }^{11}$ Manakala rekod terkini daripada ICOP mencatatkan anak bulan telah kelihatan dengan sudut elongasi $6.0^{\circ}$ yang dicerap di Amerika Syarikat dengan menggunakan

85 Islamic Crescent's Observation Project, http://www.icoproject.org/record.html., dicapai pada 2 April 2019,

86 Danjon, André-Louis, 'Jeunes et Vieilles Lunes', l'Astronomie: Bulletin De La Société Astronomique De France, vol. 46 (1932): 57-66; Fatoohi, Louay J., Stephenson, Francis Richard \& Al-Dargazelli, Shetha S., 'The Danjon Limit of First Visibility of The Lunar Crescent', The Observatory, vol. 118 (1998): 65-72.

87 Fatoohi, Louay J., Stephenson, Francis Richard \& Al-Dargazelli, Shetha S., 'The Danjon Limit of First Visibility of The Lunar Crescent', 65-72.

88 Fatoohi, Louay J., Stephenson, Francis Richard \& Al-Dargazelli, Shetha S., 'The Danjon Limit of First Visibility of the Lunar Crescent', 65-72.

89 McNally, D., 'The Length of the Lunar Crescent', Quarterly Journal of the Royal Astronomical Society, vol. 24 (1983): 417-429.

90 Dalam Resolusi Istanbul telah dicapai had kenampakan anak bulan adalah $8^{\circ}$ elongasi dan $5^{\circ}$ ketinggian. Kriteria ini dijadikan asas dalam pembentukan kriteria kenampakan anak bulan di Malaysia. Mohammad Ilyas, 'The Danjon Limit of Lunar Visibility: A Re-Examination', The Journal of The Royal Astronomical Society of Canada, vol. 77 (1983): 214-219.

91 Odeh, Mohammad Shaukat, 'New Criterion for Lunar Crescent Visibility,' 39-64. 
teleskop. ${ }^{92}$ Sultan dari Yaman pula, telah membangunkan kriteria dengan menggunakan kaedah teoritikal mendapati nilai elongasi untuk anak bulan kelihatan dengan menggunakan mata kasar adalah $7.5^{\circ}$. Manakala had elongasi bagi cerapan yang menggunakan teleskop dengan menggunakan teleskop yang sesuai adalah $5^{\circ} .{ }^{93}$ Sejumlah 74 data berjaya dikumpul oleh Amir daripada pelbagai sumber menunjukkan bahawa nilai elongasi yang dirumuskan oleh Amir adalah sama dengan nilai yang diberikan oleh McNally dan Sultan.

Pada abad yang moden, Fotheringham telah meletakkan satu kriteria altitud bulan melawan azimut bulan dan matahari selepas matahari terbenam berdasarkan 76 data cerapan anak bulan. Secara umumnya, had altitud minimum untuk anak bulan kelihatan adalah 7.70.94 Sebaliknya, Maunder seorang ahli astronomi British telah melakukan penelitian semula datadata tersebut dan menambah beberapa data cerapan anak bulan. Maunder telah merumuskan had minimum altitud anak bulan kelihatan adalah $6.0^{\circ} .{ }^{95}$ Kemudian, Ilyas telah melakukan penyelidikan semula terhadap kriteriakriteria tersebut, dengan menggunakan kaedah teoritikal Ilyas menemui nilai altitud yang paling minumum untuk anak bulan kelihatan adalah $4^{\circ} .{ }^{96}$

Dalam isu ini, pendapat al-Subkī boleh dijadikan pedoman untuk mengambil kira teknik-teknik tertentu dalam pengisbatan anak bulan. Menurut al-Subkī lagi, dalam penentuan waktu solat cukup hanya dengan pengiraan hisab falak untuk menentukan awal waktu solat dan akhir waktu solat. Terdapat nas yang jelas oleh syarak yang menunjukkan bahawa waktu tertentu sebagai sebab untuk memulakan awal waktu solat, sepertimana firman Allah SWT di dalam al-Quran:

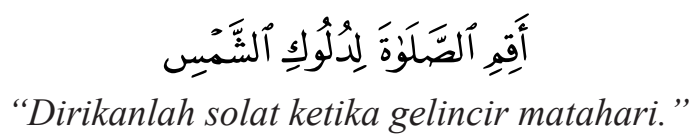

(Surah al-Isrā', 17: 78)

92 Islamic Crescent's Observation Project, http://www.icoproject.org/record. html\#optical, dicapai pada 2 April 2019.

93 Sultan, Abdul Haq, 'First Visibility of the Lunar Crescent: Beyond Danjon's Limit', 53.

94 Fotheringham, John Knight, 'On The Smallest Visible Phase of The Moon,' Monthly Notices of the Royal Astronomical Society, vol. 70 (1910): 527-531.

95 Maunder, Edward Walter, 'On The Smallest Visible Phase of The Moon', Journal of The British Astronomy Association, no. 21, 356-360.

96 Mohammad Ilyas, 'Limiting Altitude Separation in the New Moon's First Visibility Criterion’, Astronomy \& Astrophysics, vol. 206 (1988): 133-135. 
Nabi SAW juga telah bersabda:

$$
\text { وقت الظهر إذا زالت الشمس }
$$

"Waktu zohor adalah setelah gelincir matahari. " 97

Demikian itu, waktu solat zohor tersebut dapat diketahui melalui pancaindera dan dapat diketahui dengan hisab falak. Namun begitu, dalam konteks anak bulan pula bukanlah sebab adanya atau wujudnya bulan tersebut di sebalik sinaran matahari diufuk barat, tetapi kewujudannya boleh dikesan dan boleh dilihat dan mungkin boleh dilihat. Allah SWT berfirman di dalam al-Quran:

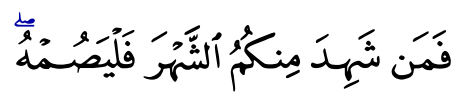

"Barang siapa di antara kamu menyaksikan bulan itu, maka berpuasalah."

(Surah al-Baqarah, 2: 185)

Manakala, Nabi SAW telah bersabda:

$$
\text { صو مو ا لرؤيته و أفطروا لرؤيته }
$$

"Berpuasalah kamu apabila melihat anak bulan dan berbukalah (berhari raya) sekiranya melihat anak bulan." 98

Oleh demikian, al-Subkī menekankan bahawa syariat Islam telah menjadikan nampaknya hilal sebagai sebab untuk berpuasa. Dalam hal ini, alSubkī juga menekankan tidak memadai memulakan awal bulan yang baharu dengan hanya berpandukan ijtimak. ${ }^{99}$ Dengan erti kata lain, permulaan bulan yang baharu perlu berpandukan kepada rukyah atau dengan lebih tepat lagi berpandukan imkān al-rukyah.

97 Hadis riwayat Muslim, Șaḥ̄ḥ Muslim, Bāb Awqāt al-Salawāt al-Khams, no. hadis 173. Lihat Muslim bin al-Hajajāj Abū al-Ḥasan al-Qushairī al-Naysābūrí, AlMusnad al-Ṣah̄h al-Mukhtașsar bi Naql al-'Adl 'An al-'Adl Ila Rasulullah s.a.w (Bayrūt: Dār Ihyā' Turāth al-‘Arabī, t.t.), 1: 427.

98 Hadis riwayat Muslim, Saḥ̄h Muslim, Bāb Wujūb Șawm Ramaḍān li Ru’yah alHilāl, no. hadis 1081/19. Lihat Abū al-Ḥusayn Muslim al-Hajjāj, Șạ̄ị Muslim, vol. 2, 762 .

99 Al-Subkī, Taqī al-Dīn 'Alī bin 'Abd al-Kāfī, Adillah fì Ithbāt al-Ahillah, 112-113. 
Pemikiran Imam Taq̄i al-Dīn al-Subkī (683/1284-756/1355) Berkaitan Kriteria Kenampakan Anak Bulan

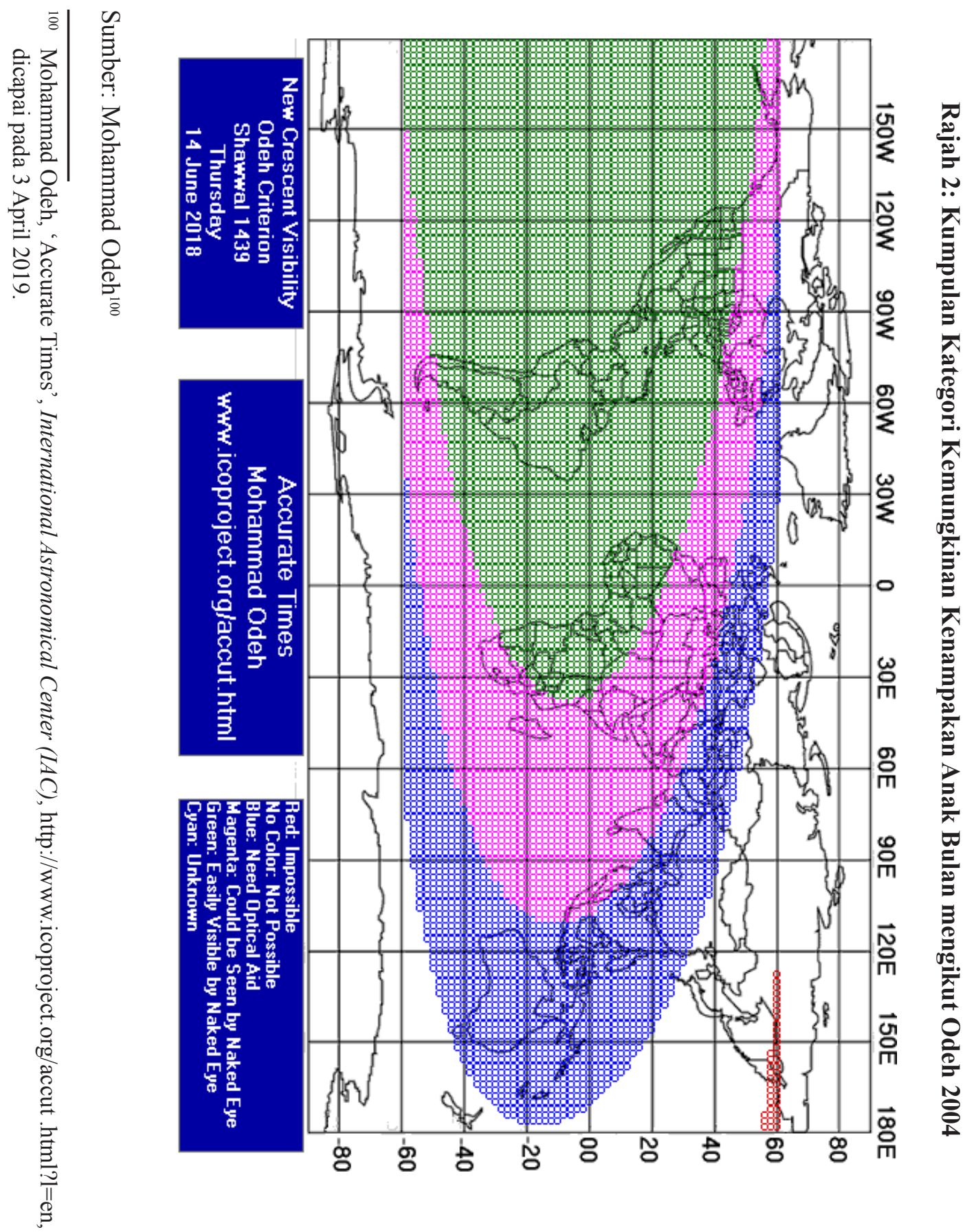


Mengikut al-Subkī, pendapat ahli falak boleh digunakan sebagai satu sumber untuk menolak kesaksian. Namun, mengikut al-Subkī ahli falak tersebut mestilah boleh dipertanggungjawabkan dari aspek agama dan keilmuannya. Dalam membahaskan persoalan kemungkinan anak bulan kelihatan, atau tidak mungkin kelihatan, al-Subkī membawakan pendapat lima pembahagian kategori keadaan anak bulan mungkin boleh kelihatan atau tidak. Pertama, anak bulan mustahil (istiḩälah) untuk dilihat. Kedua, kemungkinan anak bulan untuk kelihatan adalah sukar. Ketiga, kemungkinan anak bulan untuk kelihatan tidak begitu sukar. Keempat, kemungkinan anak bulan untuk kelihatan mudah. Kelima, kemungkinan anak bulan untuk dilihat sangat tinggi. ${ }^{101}$ Dalam konteks ini, mustahil untuk dilihat di sini bermaksud mustahil dari pandangan adat untuk anak bulan kelihatan, bukannya dari segi akal. Oleh itu, apabila anak bulan dihukumkan mustahil untuk kelihatan dari segi adat, maka dilarang kepada hakim untuk menerima penyaksian.

Dalam abad moden, Yallop, SAO, Odeh telah membagikan kenampakan anak bulan pada tarikh tertentu kepada beberapa kumpulan kategori kemungkinan kenampakan anak bulan. Contohnya seperti dalam Rajah 2 bagi menentukan 1 Syawal 1439. Cerapan dilakukan pada 29 Ramadan 1439 bersamaan 14 Jun 2018. Odeh telah membahagikan kategori kemungkinan anak bulan kelihatan kepada empat kumpulan. Pertama, negara yang dilorekkan dengan warna hijau menunjukkan kemungkinan anak bulan boleh kelihatan dengan menggunakan mata kasar adalah tinggi. Kedua, negara yang dilorekkan dengan warna biru kemungkinan anak bulan boleh kelihatan hanya dengan menggunakan instrumen astronomi. Ketiga, negara yang dilorekkan dengan warna magenta kemungkinan kenampakan bulan sabit menggunakan mata kasar. Keempat, negara yang dilorekkan dengan warna merah kemungkinan anak bulan tidak kelihatan walaupun dengan menggunakan instrumen astronomi. Kelima; tempat yang ditandakan dengan warna putih atau tidak bewarna yang menunjukkan kawasan anak bulan tidak langsung kelihatan ${ }^{102}$

Seterusnya, al-Subkī menjelaskan senario di mana sekiranya mengikut kriteria anak bulan boleh kelihatan pada 29 Shaaban, namun begitu jika terdapat halangan seperti awan, mendung atau sebagainya yang menyebabkan anak bulan tidak kelihatan. Adakah perlu ditetapkan 1 Ramadan atau dicukupkan bulan Shaaban 30 hari? Al-Subkī berpendapat bahawa ulama berbeza pendapat dalam senario ini. Pendapat pertama, pendapat yang asah, iaitu dicukupkan bulan Shaaban 30 hari, tidak harus ditetapkan 1 Ramadan. Ini kerana walaupun

\footnotetext{
101 Al-Subkī, Taqī al-Dīn 'Alī bin 'Abd al-Kāfì, Adillah fì Ithbāt al-Ahillah, 106.

102 Mohammad Odeh, 'Accurate Times', International Astronomical Center (IAC), dicapai pada 3 April 2019, https://www.astronomycenter.net/accut.html.
} 
dari segi hisab falak menunjukkan mungkin anak bulan kelihatan. Akan tetapi syarak menjadikan hisab falak sebagai perkara tambahan dan menjadikan ia sebab, maka tidak lengkap perkara tersebut tanpa rukyah. Dalam senario ini kriteria kenampakan anak bulan hanya dijadikan sebagai pembantu samaada untuk ditetapkan awal bulan yang baharu. Ini kerana walupun mengikut kriteria kenampakan anak bulan sudah mungkin untuk kelihatan, namun sekiranya tidak kelihatan maka digenapkan bulan yang berlangsung kepada 30 hari.

Kedua, anak bulan dikira boleh kelihatan dan ditetapkan sebagai 1 Ramadan kerana maksud kemunculan anak bulan merujuk kepada kebarangkalian anak bulan dapat dilihat (rukyah). Manakala, hisab boleh menggantikan rukyah kerana rukyah menjadi sukar apabila langit gelap dan mendung. ${ }^{103}$ Dalam senario ini, kriteria kenampakan anak bulan dijadikan penentu sekiranya cuaca mendung atau sebagainya. Dalam erti kata lain, sekiranya cerapan anak bulan dilakukan pada 29 Shaaban kedudukan anak bulan pada petang hari tersebut telah memenuhi kriteria kenampakan anak bulan, sedangkan anak bulan tidak kelihatan, maka keesokkan harinya akan ditetapkan sebagai 1 Ramadan.

Pada masa kini, terdapat perbezaan di antara amalan penggunaan kriteria imkān al-rukyah dalam negara-negara Islam khususnya di rantau asia tenggara. Walaupun Malaysia, Indonesia, Brunei, Singapura dan Brunei bernaung dalam kesepakatan MABIMS, namun bagi penentuan 1 Ramadan, Syawwal dan Zulhijah terdapat perbezaan khususnya bagi negara Brunei Darussalam. Walaupun negara-negara tersebut telah menerima kriteria yang disepakati yang dinamakan sebagai kriteria imkān al-rukyah MABIMS dalam penentuan 1 Ramadan, Syawal dan Zulhijah, namun negara Brunei Darusslam menggunakan rukyah sebagai penentu. Ini bermaksud walaupun kedudukan anak memenuhi kriteria imkān al-rukyah MABIMS, namum sekiranya anak bulan tidak kelihatan dicukupkan bilangan hari dalam bulan sebanyak 30 hari dalam bulan Shaaban, Ramadan mahupun Zulkaedah. Ini berbeza dengan Malaysia, Indonesia, Singapura sekiranya senario itu berlaku akan menjadikan keesokan harinya sebagai 1 Ramadan, 1 Shawal atau 1 Zulhijjah. ${ }^{104}$ Justeru, menurut al-Subkī terdapat khilaf di kalangan ulama dalam membolehkan kriteria kenampakan anak bulan dijadikan sebagai penentu mahupun pembantu.

Dalam dua pendapat yang dikemukakan oleh al-Subkī di atas, amalan menjadikan hisab sebagai penentu dan pembantu mempunyai sandaran hujah masing-masing. Dalam hal ini, pengkaji melihat urusan penentuan puasa dan

103 Al-Subkī, Taqī al-Dīn 'Alī bin 'Abd al-Kāfì, Adillah fì Ithbāt al-Ahillah, 114.

104 Hanapi, Mohd Shukri \& Shahir Akram Hassan, 'Basis for Using the Rukyah Method for Determining the Arrival of Ramadan and Syawal in Brunei Darussalam,' Journal of Islamic Studies, vol. 3, no. 2 (2015): 13-22. 
hari raya bukan melibatkan ibadah bersifat individu semata-mata, namun ia melibatkan urusan ekonomi, kebudayaan dan sosial. Oleh demikian, pemerintah sesebuah negara boleh memilih untuk bersandarkan pendapat yang boleh menjaga mașlahah masyarakat dalam sesebuah negara. Oleh demikian, dalam hal ini, contohnya negara Brunei mengamalkan hisab sebagai pembantu, mempunyai sandaran yang kuat dalam memelihara mașlah hah dalam kehidupan beragama di negara tersebut. Begitu juga, Malaysia, Indonesia dan Singapura telah mengamalkan hisab sebagai penentu mempunyai alasan tertentu untuk menjaga keharmonian kehidupan beragama di negara masing-masing.

\section{KESIMPULAN}

Penulisan ini merumuskan pendapat al-Subkī masih relevan dalam konteks semasa bagi menilai isu-isu berkaitan anak bulan. Ini diperhatikan kepada pendapat al-Subkī dalam menafsirkan hadis hadis hisab dan rukyah. Pendapat beliau boleh dijadikan sandaran dalam mengharuskan pengamalan konsep kriteria imkān al-rukyah dalam penentuan awal bulan khususnya penentuan awal puasa dan hari raya. Selanjutnya, walaupun al-Subkī hidup pada kurun ke 13, namun dalam bidang sains kenampakan anak bulan, al-Subkī dilihat telah meraikan pendapat ahli falak/astronomi mengenai kriteria kenampakan anak bulan. Beliau telah mengemukakan tiga parameter penting dalam sains kenampakan anak bulan iaitu elongasi, altitud dan lag time. Tiga parameter tersebut masih relevan sehingga telah dikembangkan oleh ahli-ahli falak/ astronomi dalam ke 19 hingga ke 21 kini. Seterusnya, apa yang menarik pendapat al-Subkī ini beliau mengariskan lima kategori keadaan anak bulan sesuai atau tidak untuk kelihatan di sesuatu tempat. Perkara ini juga masih relevan sehingga kini dan digunakan secara meluas dan ditambah baik dengan diwujudkan perisian tertentu oleh ahli falak/astronomi untuk menjelaskan idea atau konsep yang diutarakan oleh al-Subkī tersebut. Al-Subkī juga telah mengutarakan idea penggunaan kriteria imkān al-rukyah. sebagai pembantu atau penentu dalam penentuan awal puasa dan hari raya. Pendapat beliau masih relevan dalam konteks semasa kerana ia dibuktikan masih terdapat negara yang mengamalkan kriteria imkān al-rukyah. sebagai penentu seperti Malaysia, Singapura, Indonesia dalam penentuan awal puasa dan hari raya. Manakala Brunei pula mengamalkan kriteria-kriteria imkān al-rukyah sebagai pembantu khususnya dalam penentuan awal puasa dan hari raya.

\section{RUJUKAN}

'Abd al-Raḥmān bin Abī Bakr, al-Dibāj 'ala Șaḥ̄hh Muslim al-Hajjāj, vol. 3 (Riyāḍ: Dār Ibn 'Affān li Nashr wa al-Tawzī', 1995). 
'Alī Bashā Mubārak, al-Khatat al-Tawfūqiyyah al-Jadīdah li Miṣr al-Qāhirah (Qāhirah: Maṭbā'ah Dār al-Kutub wa al-Wathā'iq al-Qawmiyyah, 2001).

Al-'Aynī, Badr al-Dīn Abī Muḥammad Mạ̣mūd bin Aḥmad, 'Umdah al-Qārī Sharh Saḥịh al-Bukhārī (Bayrūt: Dār al-Kutub al-'Ilmiyyah, 2001).

'Imād 'Abd 'Azīz Mujahid, Dalīl al-Muslim al-Falakī ('Ammān: Dār Hunayn, 1994).

Abī 'Abd Allāh Muḥammad Ibn Ismā'il al-Bukhārī al-Ju'fì, Șahịh al-Bukhārī (Dimashq: Dār al-Ṭ̂uq al-Najāḥ, 2001).

Abī 'Abd Allāh Muhammad Ibn Ismā'il al-Bukhārī al-Ju'fì, Șah̄ịh al-Bukhārī (Qāhirah: al-Maṭba'ah al-Salāfiyyah, 2001).

Abī al-Ṭayyib Muḥammad Shams al-Dīn al-Ḥaq al-'Aẓīm Abadī, Sharh Sunan Abī Dāwud (Madīnah: al-Maktabah al-Salafiyyah, 1967).

Abū al-Ḥasan 'Alī bin Khalf bin 'Abd al-Mālik bin Bațtal al-Kubrā al-Qurțubī, Sharh Sah̄ịh al-Bukhārī (Riyāḍ: Maktabah al-Rushd, 2003).

Abū al-Hasan Taqī al-Dīn 'Alī 'Abd al-Kāfì al-Subkī, Fatawā al-Subkī (Qāhirah: Dār al-Ma‘ārif, t.t.).

Abū al-Husayn Muslim al-Hajjāj, Saḥ̄ḥ Muslim (Bayrūt: Dār Ihyā' Turāth al'Arabī, t.t.).

Aḥmad Ibn 'Alī Ibn Hajar al-'Asqalānī, Fatḥ al-Bārī (Riyāḍ: Maktabah alMālik Fahd al-Wațāniyyah, 2001).

Aḥmad Muhammad Shakīr, Awā'il al-Shuhūr al-'Arabiyyah: Hal Yajūz Shar'an Ithbātuha bi al-Hisāb al-Falakī? (Qāhirah: Maktabah Ibn Taymiyyah, 1937).

Al-Anșārī, Zakariyā bin Muḥammad bin Aḥmad bin Zakariyā, Fath alWahhāb bi Sharh Manhāj al-Ṭullāb: Sharh li al-Mu'allif 'alā Kitābuh Huwa Manhāj al-Ṭullāb Alladhī Ikhtasarahu al-Mu'allif min Minhāj alTālibīn li al-Nawawī (Bayrut: Dār al-Fikr li al-Tibā 'ah wa al-Nashr, 1994).

Al-Anșārī, Zakariyā bin Muḥammad bin Aḥmad bin Zakariyā, Manhāj alTullāb fì Fiqh al-Imām al-Shāfi 'ì Radì Allāh 'anh (Bayrūt: Dār al-Kutub al-'Ilmiyyah, 1997).

Al-Bujayramī, al-Tajrīd li Naf' al-'Abìd: Hāshiyah al-Bujayramī 'ala Sharh al-Manhāj (Bayrūt: Maṭba'ah al-Ḥalābī, 1950).

Danjon, André-Louis, 'Jeunes et Vieilles Lunes', l'Astronomie: Bulletin De La Société Astronomique De France, vol. 46 (1932): 57-66. 
Al-Dhahabī, al-A 'lām bi Wāfiyyat al-A 'lām, ed. Mustafā bin 'Alī bin 'Iwād dan Rabī' Abū Bakr 'Abd al-Baqī (Bayrūt: t.p., 1993).

Al-Dimyatī, Abū Bakr bin Muḥammad Shatā, I'ānah al-Ṭālibīn 'ala Hill Alfāz Fatḥ al-Mu 'ayyin (Bayrūt: Dār al-Fikr li al-Tibā'ah wa al-Nashr wa alTawzī', 1997).

Fakhar M. et al., 'Lunar Crescent Detection Based On Image Processing Algorithms', Earth, Moon and Planets, vol. 114, no. 1-2 (2014): 17-34.

Fatoohi, Louay J., Stephenson, F. Richard \& Al-Dargazelli, Shetha S., 'The Babylonian First Visibility of the Lunar Crescent: Data and Criterion,' Journal for the History of Astronomy, vol. 30 (1999): 51-72.

Fatoohi, Louay J., Stephenson, Francis Richard \& Al-Dargazelli, Shetha S., 'The Danjon Limit of First Visibility of the Lunar Crescent', The Observatory, vol. 118 (1998): 65-72.

Fotheringham, John Knight, 'On the Smallest Visible Phase of the Moon,' Monthly Notices of the Royal Astronomical Society, vol. 70 (1910): 527531.

Al-Ghamrawī, al-'Allamah Muhammad al-Zuhrī, al-Sirrāj al-Wahhāj 'ala Matn al-Minhāj (Bayrūt: Dār al-Ma'rifah li al-Tibā'ah wa al-Nashr, t.t.).

Guessoum, Nidal \& Meziane, K., 'Visibility of the Thin Lunar Crescent: The Sociology of An Astronomical Problem (A Case Study)', Journal of Astronomical History \& Heritage, vol. 4 (2001): 1-14.

Hafez, YaserA., Trojan, Lorenzo, Albaqami, Fahad H.,Almutairi,Abdulmajeed, Z., Davies, Rodney D., Dickinson, Clive \& Piccirillo, Lucio, 'A Radio Determination of the Time of the New Moon', Monthly Notices of the Royal Astronomical Society, vol. 439 (2014): 2271-2280.

Hanapi, Mohd Shukri \& Shahir Akram Hassan, 'Basis for Using the Rukyah Method for Determining the Arrival of Ramadan and Syawal in Brunei Darussalam,' Journal of Islamic Studies, vol. 3, no. 2 (2015): 13-22.

Hasanzadeh, Amir, 'Study of Danjon Limit in Moon Crescent Sighting', Astrophysics and Space Science, vol. 339 (2012): 211-221.

Ibn Kathīr, Abū al-Fidā' Ismā 'īl bin 'Umar bin Kathīr al-Qurayshī al-Basrī al-Dimashq1̄, al-Bidāyah wa al-Nihāyah, vol. 14 (Qāhirah: Dār Iḥyā' al-Turāth al-'Arabī, 2001).

Al-Juwayn̄̄, 'Abd al-Mālik bin 'Abd Allāh bin Yūsuf bin Muḥammad, Nihāyah al-Maṭlab fì Dirāyah al-Madhhāb (Bayrūt: Dār al-Minhāj, 2007).

King D.A., 'Astronomy in the Service of Islam,' in Handbook of Archaeoastronomy and Ethnoastronomy, ed. Ruggles C. (New York: Springer, 2015). 
King, David A., 'Ibn Yūnus on Lunar Crescent Visibility', Journal for the History of Astronomy, vol. 19 (1988): 155-168.

Kordi, Ayman S., 'The Psychological Effect on Sightings of The New Moon', The Observatory, vol. 123 (2003): 219-222.

Maunder, Edward Walter, 'On The Smallest Visible Phase of The Moon', Journal of The British Astronomy Association, no. 21, 356-360.

McNally, D., 'The Length of the Lunar Crescent', Quarterly Journal of the Royal Astronomical Society, vol. 24 (1983): 417-429.

Mohammad Ilyas, 'Limiting Altitude Separation in the New Moon's First Visibility Criterion', Astronomy \& Astrophysics, vol. 206 (1988): 133135.

Mohammad Ilyas, 'Lunar Crescent Visibility Criterion and Islamic Calendar', Quarterly Journal of the Royal Astronomical Society, vol. 35 (1994): 425-461.

Mohammad Ilyas, 'The Danjon Limit of Lunar Visibility: A Re-Examination', The Journal of The Royal Astronomical Society of Canada, vol. 77 (1983): 214-219.

Mohammad Ilyas, Sistem Kalendar Islam dari Perspektif Astronomi (Kuala Lumpur: Dewan Bahasa dan Pustaka, 1999).

Mohammad Odeh, 'Accurate Times', International Astronomical Center (IAC), http://www.icoproject.org/accut .html?l=en, dicapai pada 3 April 2019.

Mohd Saiful Anwar Mohd Nawawi, Saadan Man, Mohd Zambri Zainuddin, Raihana Abdul Wahab, and Nurulhuda Ahmad Zaki, 'Sejarah Kriteria Kenampakan Anak Bulan di Malaysia', Journal of al-Tamaddun, vol. 10, no. 2 (2015): 61-75.

Moosa, Ebrahim, 'Shaykh Ahmad Shākir and the Adoption of A Scientifically Based Lunar Calendar', Islamic Law and Society, no. 5 (1998): 57-89.

Muhammad Shawkah 'Awdah, 'al-Farq Bayn al-Hilāl wa Tawallad al-Hilal', Makalah Islamic Cescent's Observation Project (ICOP), dicapai pada 2 April 2019.

Muhyy al-Dīn Abū Zakariyyā bin Yahyā Sharf al-Nawawī, Minhāj Sharh Muslim al-Hajjāj (Qāhirah: Matba'ah Mișriyyah, 1980).

Mujahid Ma'mun Diraniyyah, al-Fatawā 'Alī al-Ṭantawì (Jeddah: Dār alManārah, 1986).

Muslim bin al-Hajjāj Abū al-Hasan al-Qushayrī al-Naysābūrī, al-Musnad alȘaḥị al-Mukhtașșar bi Naql al-'Adl 'an al-'Adl ila Rasulullah s.a.w. (Bayrūt: Dār Ihyā̄' Turāth al-'Arabī, t.t.). 
Al-Nahar, 'Umar Muhammad, 'Asr al-Mamālik al-Bahriyyah Dirāsah Fikriyyah (Dimashq: Dār al-Nahụah li al-Tibā'ah wa al-Nashr wa alTawzī', 2017).

Nishtaman Bashīr Muhammad, 'Al-Shaykh Taqī al-Dīn al-Subkī: Dirāsah 'An Duwarih fī al-Hayah al-Fikriyyah wa al-Qạ̣ā'iyyah', Humanities Journal of University of Zakho, vol. 5, no. 3 (2017): 676-685.

Nūr al-Dīn bin 'Abd al-Hādī Abū al-Hasan al-Sindī, Hāshiyah al-Sind̄̄ 'ala al-Nasā' '̄ (Halab: Maktabah al-Maṭba'ah al-Islāmiyyah, 1986).

Odeh, Mohammad Shaukat, 'New Criterion for Lunar Crescent Visibility', Experimental Astronomy, vol. 18 (2004): 39-64.

Al-Qastalān̄̄, Aḥmad bin Muḥammad, Irshād al-Sārī Sharh Ṣaḥ̄ḥ al-Bukhārī (Qāhirah: Dār al-Ṭabā'ah Maqsriyyah, 1980).

Al-Qaylubī, Aḥmad Salamah dan Barlasī, Aḥmad Amīrah, Hashīta Qaylubī wa 'Amīrah (Bayrut: Dār al-Fikr, 1995).

Al-Ṣafdī, A 'yān al- 'Asr wa A 'wān al-Naṣr, ed. 'Alī Abū Zayd et al. (Dimashq: t.p., 1998).

Schaefer, Bradley E., 'Lunar Crescent Visibility', Quarterly Journal of the Royal Astronomical Society, vol. 37 (1996): 759-768.

Schaefer, Bradley E., 'Visibility of the Lunar Crescent', Quarterly Journal of The Royal Astronomical Society, vol. 29 (1988): 511-523.

Al-Shāfi'î, Abū 'Abd Allāh Muḥammad bin Idrīs bin al-'Abbās bin 'Uthmān bin Shāfi'ī bin 'Abd al-Muṭallib bin 'Abd Manaf al-Muṭallib al-Quraysh̄̄ al-Makī, al- 'Umm (Bayrūt: Dār al-Ma'rifah, 1990).

Al-Sharbin̄̄, Shams al-Dīn Muḥammad bin Aḥmad al-Khātị, al-Iqnā' fì Hill Alfāz Abì Shujā' (Bayrūt: Dār al-Fikr, t.t.).

Al-Sharbinī, Shams al-Dīn Muḥammad bin Aḥmad al-Khāṭib, Mughnī alMuḥtāj Ila Ma 'rifah ma 'ānī Alfāz al-Minhāj (Bayrūt: Dār al-Kutub al'Ilmiyyah, 1994).

Sharf Qudah, 'Thubūt al-Shahr al-Qamarī Bayna al-Hadīth al-Nabawī wa 'Ilm al-Hadīth,' Majallah al-Dirāsah Jāmi 'ah Urdūn, vol. 26, no. 2 (1999): 6-10.

Sinar Harian, 'Brunei mula berpuasa Selasa,' https://www.sinarharian.com. my/article/ 26703/GLOBAL/Brunei-mula-berpuasa-Selasa, dicapai pada 8 Mei 2019. 
Al-Subkī, Tāj al-Dīn 'Abd al-Wahhāb bin Taqī al-Dīn al-Subkī, Tabaqāt alShāfi 'iyyah al-Kubrā, ed. Mạ̣mūd Muḥammad al-Thanahī dan 'Abd al-Fattāh Muhammad al-Halwī (Qāhirah: Hijr li al-Ṭibā'ah wa al-Nashr wa al-Tawzī', 1976).

Al-Subkī, Taqī al-Dīn 'Alī bin 'Abd al-Kāfī, Adillah fĩ Ithbāt al-Ahillah, ed. Samīrah Dāwud al-'Ānī (Bayrūt: Dār al-Fatḥ li al-Dirāsat wa al-Nashr, 2013).

Sultan, Abdul Haq, 'First Visibility of the Lunar Crescent: Beyond Danjon's Limit', The Observatory, vol. 127 (2007): 53-59.

Yūsuf al-Qaraḍ̄̄wī, Fiqh al-Siyām (Qāhirah: Maktabah al-Wahbah, t.t.).

Yūsuf al-Qaraḍāwī, Kayf Nata 'amal ma 'a al-Sunnah al-Nabawiyyah (Qāhirah: Dār al-Shuruq, 2005). 
Jurnal Syariah, Jil. 28, Bil. 1 (2020) 1-30 